\title{
Virulence and Fungicide Sensitivity of Phytophthora cactorum Isolated from American Ginseng Gardens in Wisconsin and Michigan
}

\author{
S. N. Hill, Graduate Research Assistant, and M. K. Hausbeck, Professor, Department of Plant Pathology, Michigan \\ State University, East Lansing 48824
}

\begin{abstract}
Hill, S. N., and Hausbeck, M. K. 2008. Virulence and fungicide sensitivity of Phytophthora cactorum isolated from American ginseng gardens in Wisconsin and Michigan. Plant Dis. 92:1183-1189.

Phytophthora cactorum causes foliar blight and root rot on cultivated ginseng (Panax quinquefolium). Commercial ginseng gardens in Wisconsin and Michigan and research gardens at Michigan State University were sampled and P. cactorum isolated. In all, 114 and 96 P. cactorum isolates were recovered in 2003 and 2004, respectively. The majority (82\%) of the isolates screened (210 in total) were resistant to the fungicide mefenoxam. P. cactorum isolates were screened for pathogenicity using 'McIntosh' apple fruit (206 isolates) and ginseng seedlings (38 isolates). Most isolates (98\%) produced necrotic lesions on apple fruit and nearly all (97\%) isolates resulted in 40 to $100 \%$ plant death. Apple fruit and ginseng seedlings were also used to test fungicide efficacy against $P$. cactorum. Mefenoxam, the industry standard, was ineffective in both the apple fruit and seedling studies when using a mefenoxam-resistant $P$. cactorum isolate. Only copper hydroxide provided consistent control against $P$. cactorum when tested on apple fruit and ginseng seedlings.
\end{abstract}

Additional keywords: ginseng seed

American ginseng (Panax quinquefolium), grown primarily for its root, is a perennial herb $(22,24)$. Ginseng is a highvalue crop, with prices ranging up to $\$ 44$ to $\$ 88 / \mathrm{kg}$ of dry root (13). More than $95 \%$ of the commercial ginseng grown in the United States is cultivated in Wisconsin (1), where approximately 400 growers raise 850 ha of ginseng (13). Woodsgrown, cultivated ginseng is a relatively new commercial crop in Michigan, with the first seedlings (Wisconsin transplants) planted in 1995 (13). Most of Michigan's production occurs in the Upper Peninsula and the majority of the acres are grown under a natural forest canopy. Based on current prices, woods-grown, cultivated ginseng represents a Michigan commodity value of over $\$ 50$ million (13). Ginseng requires intensive cultivation, including a raised plant bed, the use of a natural or artificial canopy $(2,21,23)$, and crop maintenance, including mulching, hand weeding, and application of pest-control products. Seed are produced on mature plants $(\geq 3$ years old) and require a stratification period of 18 to 22 months for growth and maturation of the seed embryo $(12,20,24,26)$. His-

Corresponding author: M. Hausbeck

E-mail: hausbec1@msu.edu

Accepted for publication 4 April 2008.

doi:10.1094/PDIS-92-8-1183

(C) 2008 The American Phytopathological Society torically, roots were harvested 4 or more years after planting; however, due to increasing disease pressure, the crop is routinely harvested after only 3 years.

Phytophthora cactorum (Lebert \& Cohn) J. Schröt (3) was first documented as a pathogen of ginseng in the United States in $1906(10,26,31)$. Cool, wet weather favors Phytophthora infection $(7,8,21,25)$. Foliar blight symptoms include dark green, water-soaked lesions on the leaves (8). Disease can progress rapidly down the main stem $(10,13)$, resulting in plant collapse and death (14). Aboveground symptoms of root rot include wilting and reddening of leaflets (8). Infected roots develop a brown discoloration (5) and a loss of turgidity gives the tissue a spongy texture.

$P$. cactorum has become an increasing disease concern among Wisconsin and Michigan growers (12). If not controlled, this pathogen may destroy an entire ginseng garden in just a few weeks $(2,7,13)$. $P$. cactorum produces oospores, chlamydospores, sporangia, and zoospores. Oospores and chlamydospores are long-lived structures with the potential for overwintering $(6,7,10)$. Sporangia may germinate directly to cause infection or differentiate into motile zoospores when saturated. Zoospores increase the potential for disease epidemics and may be disseminated via flowing water from contaminated growing sites $(5,10)$.

$P$. cactorum isolates generally are not host specific (10). This soilborne, homo- thallic oomycete pathogen infects more than 200 plant species in 150 genera representing 60 plant families. Isolates recovered from beech (Fagus sp.), yellow turk cap lily (Lilium candidum), apple (Pyrus malus), rhubarb (Rheum rhaponticum), peony (Paeonia sp.), and pine (Pinus sp.) were all highly virulent to apple fruit (30). When the pathogenicity of $P$. cactorum recovered from ginseng gardens and forest soils in Wisconsin was studied previously, isolates could colonize apple cotyledons and ginseng leaflets in vitro. However, the recovery of $P$. cactorum from either tissue was not a good predictor of pathogenicity or virulence to ginseng seedlings (7).

Historically, disease caused by $P$. cactorum has been managed with frequent use of the systemic fungicides metalaxyl or mefenoxam (27). Recently, P. cactorum isolated from strawberry roots and crowns was found to be resistant to mefenoxam (17). Additionally, isolates of $P$. cactorum recovered from ginseng were resistant to mefenoxam $(14,15)$. Other products registered for Phytophthora foliar blight and root rot of ginseng include fosetyl-al and salts of phosphorus acid, which offer a moderate level (60 to $74 \%$ ) of control against $P$. cactorum (13). A Section 18 Emergency Exemption label for use of mancozeb + zoxamide (Gavel 75DF; Dow AgroSciences LLC, Indianapolis, IN) has been available yearly for Michigan and Wisconsin for use against foliar Phytophthora blight. Captan (Captan 50W; Drexel Chemical Company, Memphis, TN) was recently labeled for use on ginseng but cannot be used within 1 year of harvest. Given the long-term survival of $P$. cactorum in the soil and the 3 year or longer cultivation of ginseng, determining the prevalence of $P$. cactorum in Wisconsin and Michigan ginseng gardens and the percentage of mefenoxam-resistant isolates in ginseng gardens has been a priority (13). The identification of alternative chemical management tools effective in limiting $P$. cactorum was also of interest.

\section{MATERIALS AND METHODS}

Field sampling and disease symptoms. During 2003 and 2004, American ginseng plants with $P$. cactorum symptoms (reddened leaflets and spongy roots) and asymptomatic plants within $92 \mathrm{~cm}$ of the disease foci were collected. In total, 47 cultivated, woods-grown, and research gardens were sampled. At least 10 plants 
per garden were collected. All Wisconsin gardens (26 in 2003 and 6 in 2004) represented cultivated commercial productions. In Michigan, ginseng was sampled from commercial woodland gardens (six in 2003) in the Upper Peninsula and cultivated research gardens (two in 2003 and one in 2004) located at the Plant Pathology and Horticulture Farms at Michigan State University (MSU), East Lansing. The research gardens at MSU were established in the spring of 2003 from 2-year-old transplanted roots obtained from the Wisconsin ginseng industry. For all locations, sampling occurred between May and August and included seedlings and 2- and 3-yearold plants. Field samples were rinsed under distilled water. Portions of leaf, stem, and root tissues were excised and embedded in water agar amended with ampicillin (2 $\mathrm{ml} /$ liter) and incubated at $25^{\circ} \mathrm{C}$ (29). After $48 \mathrm{~h}$, cultures were examined via microscopy $(\times 200)$ for characteristics of $P$. cactorum, including gnarled mycelium and papillate, ovoid sporangia $(31.4 \pm 4.8$ by $26.4 \pm 4.0 \mu \mathrm{m})(10,29)$.

Greenhouse sampling. Stratified ginseng seeds, obtained from a commercial Wisconsin garden, were germinated in an MSU research greenhouse. Prior to use, the research greenhouse surfaces were disinfested with sodium hypochlorite. Only ginseng was grown in the greenhouse. In all, 250 seeds were sown in new 3-liter aluminum pans (50 seeds each; Handi Foil Corporation, Wheeling, IL) containing autoclaved vermiculite (medium particle; Thermo-O-Rock Inc., Chandler, AZ) and sand (medium grain; Quikrete, Atlanta) (1:3, vol/vol). Pans were maintained on greenhouse benches under $63 \%$ shade cloth (Hummert International, Earth City, MO), at 18 to $26^{\circ} \mathrm{C}$ (night to day temperature) and irrigated as needed. After emergence (approximately 40 days), seedlings exhibiting darkened or wilted stems were removed from the pans and sampled as previously described for field samples.

Generating single-zoospore cultures and isolate maintenance. Hyphal tips of $P$. cactorum cultures were transferred from 1-week-old unclarified V8 juice agar (UCV8; $840 \mathrm{ml}$ of distilled water, $163 \mathrm{ml}$ of unclarified V8 juice, $3 \mathrm{~g}$ of $\mathrm{CaCO}_{3}$, and $16 \mathrm{~g}$ of Bacto agar) $(14,15)$ to dilute $\mathrm{V} 8$ juice agar $(960 \mathrm{ml}$ of distilled water, $40 \mathrm{ml}$ of unclarified V8 juice, $1.5 \mathrm{~g}$ of $\mathrm{CaCO}_{3}$, and $16 \mathrm{~g}$ of Bacto agar). Cultures were incubated at $25^{\circ} \mathrm{C}$ under ambient laboratory fluorescent lighting for 7 days and monitored for sporangia production. Single zoospores were obtained by flooding the 7day-old agar plates (100 by $15 \mathrm{~mm}$ ) with $20 \mathrm{ml}$ of sterilized distilled water chilled to $10^{\circ} \mathrm{C}$. Flooded plates were incubated at $25^{\circ} \mathrm{C}$ for $25 \mathrm{~min}$ for zoospore release (28). Aliquots $(0.25 \mathrm{ml})$ of the zoospore suspension were spread onto water agar plates (100 by $15 \mathrm{~mm}$ ) with a sterile glass rod.
After $24 \mathrm{~h}$ at $25^{\circ} \mathrm{C}$, a single germinating zoospore was selected at random, cut out of the agar under a dissecting microscope in a sterile hood, and transferred to BARP (benomyl at $25 \mathrm{ppm}$, ampicillin at 100 ppm, rifampicin at $30 \mathrm{ppm}$, and pentachloronitrobenzene at $100 \mathrm{ppm}$ )-amended UCV8 plates $(35$ by $10 \mathrm{~mm})(11,18)$. After 3 days, single-zoospore isolates were assessed for growth and stored in an incubator at $13^{\circ} \mathrm{C}$. Additionally, two 7-mm agar plugs were placed in $1.5-\mathrm{ml}$ sterile microcentrifuge tubes with two sterilized hemp seeds and $1 \mathrm{ml}$ of sterile distilled water, incubated at $25^{\circ} \mathrm{C}$ for 2 weeks under laboratory lighting, and stored at $13^{\circ} \mathrm{C}(11)$.

Koch's postulates. Koch's postulates were conducted for the $P$. cactorum isolates recovered from ginseng seedlings to confirm pathogenicity. To produce plants for inoculation, stratified ginseng seeds were germinated in silica sand in disinfested aluminum pans on greenhouse benches as previously described. Three weeks after emergence, seedlings with healthy leaves and roots were transferred to autoclaved, capped, 30-ml glass vials (VWR International Inc., Batavia, IL) containing $5 \mathrm{ml}$ of water agar. Seedlings were exposed to fluorescent lighting for 48 $\mathrm{h}$ and observed for disease symptoms. Seedlings exhibiting any symptoms of disease were excluded from the experiment.

Three $P$. cactorum isolates recovered from mature ginseng plants in 2003 and 7 from seedlings in 2004 were cultured on UCV8 under ambient laboratory conditions. One 7-mm-diameter agar plug from the actively growing edge of 7-day-old cultures of each isolate was placed at the base of each ginseng seedling in the glass vials. Inoculated seedlings were incubated in the laboratory under fluorescent light for 7 days at $25^{\circ} \mathrm{C}$. Tissue excisions ( 2 by 2 $\mathrm{mm}$ ) from discolored roots and stems of the inoculated seedlings were embedded in water agar, incubated under fluorescent lighting for 3 days at $25^{\circ} \mathrm{C}$, and assessed for mycelial growth. P. cactorum was identified by microscopy using morphological characteristics $(4,10)$. Each isolate was tested twice.

Mefenoxam sensitivity screening. $P$. cactorum isolates (114 from 2003 and 96 from 2004) were removed from long-term storage, transferred to UCV8, and incubated at $25^{\circ} \mathrm{C}$ for 7 days under laboratory lighting. To screen for the in vitro response to mefenoxam, agar plugs $(7 \mathrm{~mm}$ in diameter) of each $P$. cactorum isolate were placed in the center of each of two UCV8 plates amended with mefenoxam $(48 \%$ a.i., suspended in sterile distilled water and added to V8 juice agar cooled to $49^{\circ} \mathrm{C}$; Ridomil Gold EC; Syngenta Crop Protection Inc, Greensboro, NC) at 0 and 100 ppm $(14,15,18,19)$. The plates were incubated at $25^{\circ} \mathrm{C}$ for 3 days under fluorescent lighting. Isolates were assigned a me- fenoxam sensitivity rating based on the percentage of radial mycelial growth on the amended UCV8 when compared with the $0 \mathrm{ppm}$ control (9). Isolates were classified as sensitive to mefenoxam if the mycelial growth on the amended agar was $<10 \%$ of the control and resistant if growth was $>10 \%$ when compared with the control.

Virulence screening on apple fruit. In all, 111 (2003) and 95 (2004) P. cactorum isolates were screened for virulence $(10,30)$. 'McIntosh' apple fruit (approximately $110 \mathrm{~g}$ each) purchased from a commercial supplier were washed in warm water with dish soap, rinsed in distilled water, and allowed to dry prior to inoculation. Apple fruit were wounded to the depth of $10 \mathrm{~mm}$ approximately $45 \mathrm{~mm}$ away from the stem with a pushpin dipped in $70 \%$ ethanol. Agar plugs $(7 \mathrm{~mm})$ were cut from 7-day-old P. cactorum cultures grown on UCV8. One mycelial plug of each isolate was placed, mycelial side down, over the wound and plugs were covered with a $1.5-\mathrm{ml}$ microcentrifuge tube, with the cap removed, and secured to the apple surface with petroleum jelly. Four apple fruit per isolate were inoculated.

Unwounded apple fruit and wounded fruit inoculated with sterile UCV8 plugs served as controls. Inoculated and control apple fruit were placed in disinfested aluminum foil pans (6 liters) with a wet paper towel to maintain high humidity. A completely randomized arrangement was used. The pans were covered with plastic wrap and the fruit were incubated for 1 week at $22^{\circ} \mathrm{C}$ under fluorescent lighting. The area of the fruit covered with a necrotic lesion was estimated as $0,25,50,75$, or $100 \%$ of the entire apple fruit. To ensure that the lesions on the apple fruit were produced by $P$. cactorum, tissue from the edges of the lesions were excised and plated on water agar at the termination of the study. Plates were evaluated microscopically for $P$. $c a c$ torum after 3 days of incubation at $22^{\circ} \mathrm{C}$ under fluorescent lighting. The study was conducted twice.

Virulence screening on ginseng seedlings. Stratified ginseng seeds were germinated as previously described for the Koch's postulates studies. Three weeks after emergence, healthy seedlings were individually transplanted into new 89-by64-mm pots filled with autoclaved vermiculite and sand as previously described. Potted seedlings were maintained in the greenhouse under $63 \%$ shade cloth with night and day temperatures between 18 and $26^{\circ} \mathrm{C}$. Pots were arranged in a completely randomized block design with eight seedlings per isolate and irrigated as needed. $P$. cactorum isolates were selected (38 in total from 2003 and 2004) for virulence screening. Inoculum was produced by growing the isolates for 7 days on dilute V8 juice agar. For each isolate, two culture 
plates with sporulating $P$. cactorum were flooded with $20 \mathrm{ml}$ of sterilized distilled water chilled to $10^{\circ} \mathrm{C}$ and incubated at $25^{\circ} \mathrm{C}$ for $25 \mathrm{~min}$ to release zoospores. The zoospore suspension $(2 \mathrm{ml})$ was injected into the potting medium at the stem base of the seedlings. Seedlings were inoculated on 29 April 2005 and plant death was assessed 5, 7, and 10 days post inoculation (dpi). A second study was conducted with seedlings inoculated on 13 May and plant death assessed 4, 6, and 10 dpi. Data were subjected to analysis of variance (ANOVA) and a Fisher's least significant difference test (SAS Institute Inc. Cary, N.C.) $(P=$ $0.05)$.

Fungicide efficacy screening on apple fruit. McIntosh apple fruit, purchased from a commercial supplier, were used to screen various chemical treatments, including reduced-risk products and biopesticides for activity against $P$. cactorum (Table 1). A mefenoxam-resistant isolate (W38) was used to test the efficacy of each product. This isolate was recovered from a commercial field in Wisconsin in 2003 and was selected because of its consistent growth and sporulation in culture on UCV8. In preliminary studies, the isolate was highly virulent on 2- and 3-year-old roots (data not presented). Apple fruit were cleaned and wounded as previously described. Immediately following wounding, the fruit (six per treatment) were treated with fungicides until runoff using a hand-pump compressed-air sprayer. Treated apple fruit were allowed to dry before they were inoculated and placed in disinfested aluminum foil pans (6 liters) for incubation. Controls consisted of unwounded apple fruit and fruit that were wounded and sprayed with distilled water. All fruit were arranged in a completely randomized design.

Lesion development was evaluated $7 \mathrm{dpi}$ and lesion diameters were recorded and averaged per treatment. The number of infected apple fruit for each treatment also was recorded. Fruit were wiped with a $70 \%$ ethanol solution and tissue from the edge of lesions was excised and placed onto water agar to confirm $P$. cactorum as the pathogen. The study was conducted twice. Data were subjected to ANOVA, and a Fisher's least significant difference test $(P=0.05)$ was used to compare lesion diameters.

Fungicide efficacy screening on ginseng seedlings. Stratified ginseng seeds were germinated as previously described for Koch's postulates. Healthy seedlings were hand planted into new 89-by-64-mm pots filled with autoclaved vermiculite and sand and maintained in the greenhouse as previously described. The mefenoxamresistant $P$. cactorum isolate (W38) that was used for apple inoculation and fungicide screens was grown on dilute V8 juice agar for 7 days at $25^{\circ} \mathrm{C}$ under fluorescent light. Six 7-day-old UCV8 culture plates with sporulating $P$. cactorum were flooded with $20 \mathrm{ml}$ of $10^{\circ} \mathrm{C}$ sterilized distilled water and incubated at $25^{\circ} \mathrm{C}$ for $25 \mathrm{~min}$ to release zoospores. Fungicide treatments were applied as a drench in sufficient volume to displace approximately $10 \%$ of the liquid in the pots. Plants were arranged in a completely randomized block design with eight plants per treatment. The zoospore suspension $(2 \mathrm{ml})$ was injected into the potting medium at the base of each seedling immediately after the fungicide treatments were applied. Distilled water was injected into the potting medium for control plants. This study was conducted twice in 2004. In the first study, ginseng seedlings were treated and inoculated on 26 April and plant death was assessed 9, 12 , and $14 \mathrm{dpi}$. In the second study, plants were inoculated on 3 May and plant death was assessed 9, 15, and 24 dpi. A third study was conducted in 2006 using a new seed lot obtained from a commercial ginseng garden in Wisconsin. Plants were treated and inoculated on 13 June and plant death was assessed $3,6,8$, and 15 dpi. The percentage of plants dead for each treatment was determined for each assessment date and the data subjected to ANOVA and Student-Newman-Keuls test $(P=0.05)$.

\section{RESULTS}

Incidence of $\boldsymbol{P}$. cactorum and sensitivity to mefenoxam. Over the course of the study, root rot caused by $P$. cactorum was a significant problem in Michigan and Wisconsin ginseng gardens. Disease symptoms were observed and included leaf reddening, plant wilting, and spongy, rotted roots. The pathogen was confirmed in $47 \%$ (14) of the Wisconsin ginseng gardens sampled during 2003 and 2004. In total, 72 and 42 $P$. cactorum isolates were recovered from

Table 1. Products tested for Phytophthora cactorum disease management on 'McIntosh' apple fruit and ginseng seedlings

\begin{tabular}{llc}
\hline Product & Active ingredient & Formulated product per liter \\
\hline Acrobat 50WP & Dimethomorph & $0.48 \mathrm{~g}$ \\
Aliette 80WDG & Fosetyl-al $^{\mathrm{x}}$ & $6.0 \mathrm{~g}$ \\
Bravo Weather Stik 6SC & Chlorothalonil & $3.72 \mathrm{ml}$ \\
Cabrio 20EG & Pyraclostrobin & $0.3 \mathrm{~g}$ \\
Captan 80WDG & Captan & $3.0 \mathrm{~g}$ \\
Curzate 60DF & Cymoxanil & $0.24 \mathrm{~g}$ \\
Dithane 75DF & Mancozeb & $1.8 \mathrm{~g}$ \\
Endorse 2.5WP & Polyoxin D zinc salt & $2.65 \mathrm{~g}$ \\
Gavel 75DF & Mancozeb + zoxamide & $2.4 \mathrm{~g}$ \\
Kocide 2000 54DF & Copper hydroxide & $3.6 \mathrm{~g}$ \\
Omega 500F & Fluazinam & $0.62 \mathrm{ml}$ \\
Phostrol 4.32EC & Phosphorus salts & $10.0 \mathrm{ml}$ \\
Pristine 38WG & Pyraclostrobin + boscalid & $0.3 \mathrm{~g}$ \\
Previcur Flex 6F & Propamocarb & $1.49 \mathrm{ml}$ \\
Quadris 2.08SC & Azoxystrobin & $0.95 \mathrm{ml}$ \\
Ranman 400 SC & Cyazofamid & $0.12 \mathrm{ml}$ \\
Reason 500SC & Fenamidone & $0.31 \mathrm{ml}$ \\
Ridomil Gold 4EC & Mefenoxam & $0.9 \mathrm{ml}$ \\
Tanos 50WG & Famoxadone + cymoxanil & $0.75 \mathrm{~g}$ \\
Zoxium 80WP & Zoxamide & $0.37 \mathrm{~g}$ \\
\hline
\end{tabular}

${ }^{\mathrm{x}}$ Labeled for $P$. cactorum on ginseng.

${ }^{\mathrm{y}}$ Labeled for ginseng.

${ }^{\mathrm{z}}$ Section 18 exemption of federal and state agencies for emergency use.
Wisconsin ginseng gardens in 2003 and 2004, respectively. In 2004, 48 additional $P$. cactorum isolates were recovered from ginseng seedlings grown from commercial Wisconsin seed in MSU research greenhouses. $P$. cactorum (23 isolates) was recovered from five of six Michigan ginseng gardens sampled in 2003. Research gardens located at MSU yielded 19 (2003) and 6 (2004) isolates.

Most of the $P$. cactorum isolates collected were resistant to mefenoxam (Table 2 ). Of the $P$. cactorum isolates retrieved from Wisconsin gardens during 2003 and 2004 (total $=144$ ), $85 \%$ were resistant to mefenoxam. Of the 48 isolates recovered from MSU greenhouse seedlings (seed originated from Wisconsin) in 2004, $98 \%$ were resistant to mefenoxam. Nearly onehalf $(48 \%)$ of the isolates recovered from Michigan gardens in 2003 were mefenoxam resistant.

Virulence screening. Of the $111 P$. cactorum isolates screened for virulence on McIntosh apple fruit in 2003, $79 \%$ produced necrotic lesions spanning $25 \%$ of the total fruit surface area. Nineteen isolates $(17 \%)$ produced lesions spanning $50 \%$ of the apple surface. Only four isolates produced surface lesions covering $\leq 25 \%$. In 2004, of the 95 isolates screened, 94\% produced necrotic lesions spanning $25 \%$ of the fruit surface. Five isolates produced surface lesions covering $50 \%$ of the apple. Only one isolate produced lesions covering $\leq 25 \%$. Zoospore inoculation of ginseng seedlings resulted in severe disease. For Wisconsin, Michigan, and MSU isolates, $\geq 80,50$, and $\geq 80 \%$ of isolates, respectively, resulted in $\geq 75 \%$ plant death by the final observation in both replications (Table 2).

Fungicide efficacy screening on apple fruit. In study 1 , significant differences $(P$ 
$=0.05)$ in disease control were observed among the fungicide treatments. Dimethomorph, copper hydroxide, mancozeb + zoxamide, and fenamidone consistently protected apple fruit from disease when compared with the untreated control (Table $3)$. Significant differences were not consistently detected among the untreated and remaining treatments.

In the second study, dimethomorph provided complete control against $P$. cactorum in each replication. In two of the three replications, mancozeb and famoxadone + cymoxanil were significantly better than the untreated control (Table 4). Mefenoxam-treated apple fruit were similar to untreated fruit in two of the three replications.

Fungicide efficacy screening on ginseng seedlings. Disease pressure was severe in both studies conducted in 2004, with $\geq 75 \%$ of the untreated inoculated plants dead by the final observation. Copper hydroxide completely prevented plant death. Applications of dimethomorph, phosphorus salts, and fosetyl-al limited plant death to $25 \%$ in the first study and were significantly better than the untreated control (Table 5). However, in the second study, although dimethomorph significantly limited plant disease $(\leq 25 \%)$, phosphorus salts and fosetyl-al did not provide adequate protection and at least $75 \%$ of the plants died by the final rating. Mancozeb and mancozeb + zoxamide limited plant death to $37.5 \%$ at the final rating for both

Table 2. Mefenoxam sensitivity and virulence of Wisconsin and Michigan Phytophthora cactorum isolates from ginseng on apple fruit and ginseng seedlings

\begin{tabular}{|c|c|c|c|c|c|}
\hline \multirow[b]{2}{*}{ Isolate $^{w}$} & \multirow[b]{2}{*}{$\operatorname{Age}^{\mathrm{x}}$} & \multirow[b]{2}{*}{ Sensitivity ${ }^{\mathbf{y}}$} & \multirow[b]{2}{*}{ Surface area blighted $(\%)^{\mathrm{z}}$} & \multicolumn{2}{|c|}{ Seedling death $(\%)^{\mathrm{v}}$} \\
\hline & & & & Rep 1 & $\operatorname{Rep} 2$ \\
\hline W4 & 3 & $\mathrm{R}$ & 25 & $87.5 \mathrm{de}$ & $75.0 \mathrm{bcd}$ \\
\hline W15 & 3 & $\mathrm{R}$ & 25 & $100.0 \mathrm{e}$ & $100.0 \mathrm{~d}$ \\
\hline W34 & 2 & $\mathrm{R}$ & 50 & $50.0 \mathrm{bc}$ & $50.0 \mathrm{abc}$ \\
\hline W37 & 2 & $\mathrm{~S}$ & 25 & $62.5 \mathrm{bcd}$ & $75.0 \mathrm{bcd}$ \\
\hline W38 & 2 & $\mathrm{R}$ & 25 & $100.0 \mathrm{e}$ & $87.5 \mathrm{~cd}$ \\
\hline MSU39 & 2 & $\mathrm{R}$ & 0 & $50.0 \mathrm{bc}$ & $50.0 \mathrm{abc}$ \\
\hline MSU40 & 2 & $\mathrm{R}$ & 25 & $87.5 \mathrm{de}$ & $100.0 \mathrm{~d}$ \\
\hline MSU48 & 2 & $\mathrm{~S}$ & 25 & $100.0 \mathrm{e}$ & $87.5 \mathrm{~cd}$ \\
\hline M64 & 1 & $\mathrm{R}$ & 50 & $50.0 \mathrm{bc}$ & $50.0 \mathrm{abc}$ \\
\hline M76 & 2 & $\mathrm{~S}$ & 25 & 75.0 cde & $87.5 \mathrm{~cd}$ \\
\hline W87 & 2 & $\mathrm{R}$ & 25 & $100.0 \mathrm{e}$ & $87.5 \mathrm{~cd}$ \\
\hline W96 & 2 & $\mathrm{R}$ & 25 & $100.0 \mathrm{e}$ & $87.5 \mathrm{~cd}$ \\
\hline W98 & 2 & $\mathrm{~S}$ & 25 & $87.5 \mathrm{de}$ & $75.0 \mathrm{bcd}$ \\
\hline MSU121 & 1 & $\mathrm{R}$ & 25 & $87.5 \mathrm{de}$ & $87.5 \mathrm{~cd}$ \\
\hline MSU123 & 1 & $\mathrm{R}$ & 25 & $100.0 \mathrm{e}$ & $100.0 \mathrm{~d}$ \\
\hline MSU128 & 1 & $\mathrm{~S}$ & 50 & $50.0 \mathrm{bc}$ & $50.0 \mathrm{abc}$ \\
\hline MSU133 & 1 & $\mathrm{~S}$ & 25 & $100.0 \mathrm{e}$ & $87.5 \mathrm{~cd}$ \\
\hline MSU138 & 1 & $\mathrm{R}$ & 25 & $62.5 \mathrm{bcd}$ & $62.5 \mathrm{bcd}$ \\
\hline MSU141 & 1 & $\mathrm{R}$ & 25 & $87.5 \mathrm{de}$ & $87.5 \mathrm{~cd}$ \\
\hline MSU142 & 1 & $\mathrm{R}$ & 25 & $62.5 \mathrm{bcd}$ & $100.0 \mathrm{~d}$ \\
\hline MSU144 & 1 & $\mathrm{R}$ & 25 & $87.5 \mathrm{de}$ & $75.0 \mathrm{bcd}$ \\
\hline MSU151 & 1 & $\mathrm{R}$ & 25 & $87.5 \mathrm{de}$ & $87.5 \mathrm{~cd}$ \\
\hline MSU155 & 1 & $\mathrm{R}$ & 25 & $100.0 \mathrm{e}$ & $87.5 \mathrm{~cd}$ \\
\hline MSU157 & 1 & $\mathrm{R}$ & 25 & $100.0 \mathrm{e}$ & $87.5 \mathrm{~cd}$ \\
\hline MSU158 & 1 & $\mathrm{R}$ & 25 & $100.0 \mathrm{e}$ & $100.0 \mathrm{~d}$ \\
\hline MSU159 & 1 & $\mathrm{R}$ & 25 & 75.0 cde & $87.5 \mathrm{~cd}$ \\
\hline MSU162 & 1 & $\mathrm{R}$ & 25 & $87.5 \mathrm{de}$ & $87.5 \mathrm{~cd}$ \\
\hline MSU166 & 1 & $\mathrm{R}$ & 25 & $87.5 \mathrm{de}$ & $100.0 \mathrm{~d}$ \\
\hline MSU171 & 1 & $\mathrm{R}$ & 25 & $100.0 \mathrm{e}$ & $100.0 \mathrm{~d}$ \\
\hline W176 & 2 & $\mathrm{R}$ & 25 & $100.0 \mathrm{e}$ & $87.5 \mathrm{~cd}$ \\
\hline W177 & 2 & $\mathrm{R}$ & 25 & $100.0 \mathrm{e}$ & $100.0 \mathrm{~d}$ \\
\hline W178 & 2 & $\mathrm{R}$ & 25 & 75.0 cde & $87.5 \mathrm{~cd}$ \\
\hline W191 & 3 & $\mathrm{R}$ & 25 & $87.5 \mathrm{de}$ & $87.5 \mathrm{~cd}$ \\
\hline W193 & 1 & $\mathrm{~S}$ & 25 & $100.0 \mathrm{e}$ & $75.0 \mathrm{bcd}$ \\
\hline W205 & 1 & $\mathrm{~S}$ & 25 & $100.0 \mathrm{e}$ & $75.0 \mathrm{bcd}$ \\
\hline W207 & 1 & $\mathrm{R}$ & 25 & $100.0 \mathrm{e}$ & $87.5 \mathrm{~cd}$ \\
\hline W209 & 1 & $\mathrm{R}$ & 25 & $100.0 \mathrm{e}$ & $100.0 \mathrm{~d}$ \\
\hline W221 & 3 & $\mathrm{R}$ & 25 & $37.5 \mathrm{~b}$ & $50.0 \mathrm{abc}$ \\
\hline Control & $\ldots$ & 0 & 0 & $0.0 \mathrm{a}$ & $0.0 \mathrm{a}$ \\
\hline
\end{tabular}

${ }^{\mathrm{v}}$ Percentage of ginseng seedlings dead 10 days postinoculation with P. cactorum isolates. Column means with a letter in common are not significantly different (Fisher's least significant difference, $P$ $=0.05$ ).

${ }^{\mathrm{w}}$ Isolates are labeled according to the following code: $\mathrm{W}=$ Wisconsin garden, MSU $=$ Michigan State University garden or greenhouse, and $\mathrm{M}=$ Michigan garden. Control represents a sterile unclarified V8 juice agar (UCV8) plug.

${ }^{x}$ Age of ginseng isolates recovered (years).

${ }^{y}$ In vitro mefenoxam sensitivity based on the percentage of growth on UCV8 plates amended with mefenoxam at $100 \mathrm{ppm}$ when compared with control plates. $\mathrm{R}=$ mefenoxam-resistant isolate with $>10 \%$ growth of the control and $\mathrm{S}=$ mefenoxam-sensitive isolate with $\leq 10 \%$ growth of the control.

${ }^{\mathrm{z}}$ Percent surface of McIntosh apple fruit blighted at 7 days postinoculation with P. cactorum isolates. Results shown are averaged over two replications. studies but did not differ significantly from the untreated control in the first study. Plant death for fenamidone-treated plants was limited to $25 \%$ in the first study and was significantly better than the untreated control but reached $50 \%$ in the second study. Mefenoxam, the industry standard, performed poorly in both of these studies which utilized a mefenoxam-insensitive isolate. All other treatments (cyazofamid, zoxamide, and fluazinam) resulted in $\geq 50 \%$ plant death at the final evaluation and offered little disease control (Table 5).

For the third study conducted in 2006, disease pressure in the untreated inoculated plants was lower than that observed in the previous studies, with plant death not exceeding $50 \%$ until the final evaluation (Table 6). Plant death reached 25 and $50 \%$ for fosetyl-al- and phosphorus saltstreated plants, respectively. Mefenoxam and zoxamide treatments were not significantly different from the untreated control, with $75 \%$ plant death. All other treatments, including those products that performed favorably in the previous study (i.e., mancozeb, mancozeb + zoxamide, fenamidone, dimethomorph, and copper hydroxide) completely prevented plant death.

\section{DISCUSSION}

$P$. cactorum is recognized worldwide as a pathogen of numerous crops (10) and can be especially devastating on ginseng (7,10,13-15), when conditions are wet and favorable for disease. Although $P$. cactorum has previously been recovered from ginseng gardens in Wisconsin (7), the pathogen had not been detected in Michigan prior to this study (14). The recovery of $P$. cactorum from ginseng seedlings grown in a sterilized medium in the greenhouse suggests that $P$. cactorum may be transmitted via the seed. Seed transmission in addition to transplanting roots to establish ginseng gardens may increase the prevalence of $P$. cactorum in commercial gardens. It is suspected that $P$. cactorum was introduced to Michigan's Upper Peninsula commercial plantings and to the research gardens at MSU via transplanted roots obtained from Wisconsin growers. Although $P$. cactorum may survive in soil and on plant debris (13), ginseng growers do not plant ginseng on sites previously cultivated to the crop. Genetic analysis of the isolates recovered from both Wisconsin and Michigan could determine if there are similarities between isolates of both states as well as similarities among isolates from a single garden.

$P$. cactorum has been documented as non-host specific and virulent on apple fruit $(10,30)$. After 7 days of incubation, the majority of screened isolates produced lesions beyond the inoculation site, covering $25 \%$ of the apple fruit surface. When the incubation time was extended to 14 days, many isolates produced lesions that covered $100 \%$ of the apple fruit surface. 
Previous pathogenicity studies have shown that apple cotyledons and ginseng leaflets could be colonized by isolates of $P$. cactorum recovered from American ginseng (7). Our results indicate that apple fruit also may be used, because the majority of isolates screened were pathogenic on both apple fruit and ginseng seedlings. Only one isolate of $P$. cactorum that was pathogenic on ginseng seedlings was not pathogenic on apple fruit. In assessing pathogenicity of isolates, the use of apple fruit can be beneficial when healthy ginseng plants are not available.
In comparing the apple fruit and ginseng seedling virulence results, only four isolates were equally virulent in both studies. There was no correlation between the percentage of apple fruit blighted and the number of ginseng seedlings that died following inoculation. For this reason, the

Table 3. Efficacy of registered and unregistered fungicides for the control of a mefenoxam-resistant Phytophthora cactorum isolate on 'McIntosh' apple fruit (study 1)

\begin{tabular}{|c|c|c|c|c|c|c|}
\hline \multirow[b]{2}{*}{ Treatments, rate/liter } & \multicolumn{3}{|c|}{ No. of diseased fruit ${ }^{x}$} & \multicolumn{3}{|c|}{ Lesion diameter $(\mathrm{cm})^{\mathrm{y}}$} \\
\hline & $\operatorname{Rep} 1$ & $\operatorname{Rep} 2$ & $\operatorname{Rep} 3$ & $\operatorname{Rep} 1$ & $\operatorname{Rep} 2$ & $\operatorname{Rep} 3$ \\
\hline Untreated inoculated & 6 & 4 & 5 & $5.5 \mathrm{c}$ & $2.7 \mathrm{c}$ & $2.8 \mathrm{~b}$ \\
\hline Dimethomorph, $0.48 \mathrm{~g}$ & 0 & 0 & 0 & $0.0 \mathrm{a}$ & $0.0 \mathrm{a}$ & $0.0 \mathrm{a}$ \\
\hline Copper hydroxide, $3.6 \mathrm{~g}$ & 0 & 0 & 0 & $0.0 \mathrm{a}$ & $0.0 \mathrm{a}$ & $0.0 \mathrm{a}$ \\
\hline Fenamidone, $0.31 \mathrm{ml}$ & 2 & 1 & 1 & $1.4 \mathrm{a}$ & $0.4 \mathrm{a}$ & $0.2 \mathrm{a}$ \\
\hline Phosphorus salts, $10.0 \mathrm{ml}^{\mathrm{z}}$ & 2 & 1 & 5 & $1.4 \mathrm{a}$ & $0.3 \mathrm{a}$ & $1.9 \mathrm{~b}$ \\
\hline Mancozeb + zoxamide, $2.4 \mathrm{~g}$ & 5 & 0 & 1 & $3.0 \mathrm{~b}$ & $0.0 \mathrm{a}$ & $0.6 \mathrm{a}$ \\
\hline Fosetyl-al, $6.0 \mathrm{~g}^{\mathrm{z}}$ & 6 & 2 & 2 & $5.0 \mathrm{c}$ & $1.3 \mathrm{abc}$ & $0.4 \mathrm{a}$ \\
\hline Cyazofamid, $0.12 \mathrm{ml}$ & 6 & 2 & 2 & $4.4 \mathrm{bc}$ & $1.0 \mathrm{ab}$ & $0.3 \mathrm{a}$ \\
\hline Mefenoxam, $0.9 \mathrm{ml}^{\mathrm{z}}$ & 5 & 4 & 6 & $5.0 \mathrm{c}$ & $2.3 \mathrm{bc}$ & $2.8 \mathrm{~b}$ \\
\hline
\end{tabular}

${ }^{x}$ Number of infected fruit out of six inoculated.

${ }^{y}$ Diameter listed is average of six fruit. Column diameters followed by the same letters are not significantly different (Fisher's least significant difference, $P$ $=0.05$ ).

${ }^{\mathrm{z}}$ Registered for $P$. cactorum management on ginseng.

Table 4. Efficacy of registered and unregistered fungicides for the control of a mefenoxam-resistant Phytophthora cactorum isolate on 'McIntosh' apple fruit (study 2)

\begin{tabular}{|c|c|c|c|c|c|c|}
\hline \multirow[b]{2}{*}{ Treatments, rate/liter } & \multicolumn{3}{|c|}{ No. of diseased fruit ${ }^{\mathrm{x}}$} & \multicolumn{3}{|c|}{ Lesion diameter $(\mathrm{cm})^{\mathrm{y}}$} \\
\hline & Rep 1 & $\operatorname{Rep} 2$ & $\operatorname{Rep} 3$ & Rep 1 & $\operatorname{Rep} 2$ & $\operatorname{Rep} 3$ \\
\hline Untreated inoculated & 6 & 5 & 5 & $5.6 \mathrm{e}$ & $4.3 \mathrm{~cd}$ & $3.8 \mathrm{bc}$ \\
\hline Dimethomorph, $0.48 \mathrm{~g}$ & 0 & 0 & 0 & $0.0 \mathrm{a}$ & $0.0 \mathrm{a}$ & $0.0 \mathrm{a}$ \\
\hline Mancozeb, $1.8 \mathrm{~g}$ & 0 & 0 & 5 & $0.0 \mathrm{a}$ & $0.0 \mathrm{a}$ & $3.9 \mathrm{bc}$ \\
\hline Pyraclostrobin, $0.3 \mathrm{~g}$ & 4 & 4 & 4 & 3.5 bcde & $3.6 \mathrm{~cd}$ & $3.4 \mathrm{bc}$ \\
\hline Pyraclostrobin + boscalid, $0.3 \mathrm{~g}$ & 1 & 6 & 4 & $4.9 \mathrm{de}$ & $3.5 \mathrm{~cd}$ & $4.5 \mathrm{bc}$ \\
\hline Cymoxanil, $0.24 \mathrm{~g}$ & 2 & 4 & 6 & 3.4 bcde & $5.4 \mathrm{~d}$ & $4.5 \mathrm{bc}$ \\
\hline Polyoxin D zinc salt, $2.65 \mathrm{~g}$ & 3 & 5 & 5 & $4.0 \mathrm{cde}$ & $3.5 \mathrm{~cd}$ & $4.9 \mathrm{c}$ \\
\hline Propamocarb, $1.49 \mathrm{ml}$ & 3 & 6 & 6 & $5.4 \mathrm{e}$ & $4.4 \mathrm{~cd}$ & $5.5 \mathrm{c}$ \\
\hline Zoxamide, $0.37 \mathrm{~g}$ & 3 & 2 & 5 & $1.2 \mathrm{ab}$ & $4.5 \mathrm{~cd}$ & $3.3 \mathrm{bc}$ \\
\hline Azoxystrobin, $0.95 \mathrm{ml}$ & 5 & 4 & 3 & 3.5 bcde & $4.9 \mathrm{~d}$ & $2.2 \mathrm{ab}$ \\
\hline Chlorothalonil, $3.72 \mathrm{ml}$ & 5 & 5 & 5 & $4.5 \mathrm{cde}$ & $4.0 \mathrm{~cd}$ & $4.0 \mathrm{bc}$ \\
\hline Famoxadone + cymoxanil, $0.75 \mathrm{~g}$ & 5 & 2 & 6 & $2.9 \mathrm{bcd}$ & $1.0 \mathrm{ab}$ & $4.4 \mathrm{bc}$ \\
\hline Fluazinam, $0.62 \mathrm{ml}$ & 6 & 4 & 5 & 3.5 bcde & $3.4 \mathrm{bcd}$ & $4.3 \mathrm{bc}$ \\
\hline Mefenoxam, $0.9 \mathrm{ml}^{\mathrm{z}}$ & 5 & 4 & 6 & $2.5 \mathrm{bc}$ & $2.5 \mathrm{bc}$ & $5.5 \mathrm{c}$ \\
\hline
\end{tabular}

${ }^{x}$ Number of infected fruit out of six inoculated.

${ }^{\text {y }}$ Diameter listed is average of six fruit. Column diameters followed by the same letters are not significantly different (Fisher's least significant difference, $P$ $=0.05$ ).

${ }^{\mathrm{z}}$ Registered for P. cactorum management on ginseng.

Table 5. Evaluation of registered and unregistered fungicides for the control of a mefenoxam-resistant Phytophthora cactorum isolate on ginseng seedlings, 2004

\begin{tabular}{|c|c|c|c|c|c|c|}
\hline \multirow[b]{3}{*}{ Treatments, rate/liter } & \multicolumn{6}{|c|}{ Seedlings death $(\%)^{y}$} \\
\hline & \multicolumn{3}{|c|}{ Study 1} & \multicolumn{3}{|c|}{ Study 2} \\
\hline & 5 May & 8 May & 10 May & 12 May & 18 May & 27 May \\
\hline Untreated inoculated & $75.0 \mathrm{~cd}$ & $75.0 \mathrm{bc}$ & $75.0 \mathrm{bc}$ & $75.0 \mathrm{c}$ & $87.5 \mathrm{~d}$ & $87.5 \mathrm{~d}$ \\
\hline Copper hydroxide, $3.6 \mathrm{~g}$ & $0.0 \mathrm{a}$ & $0.0 \mathrm{a}$ & $0.0 \mathrm{a}$ & $0.0 \mathrm{a}$ & $0.0 \mathrm{a}$ & $0.0 \mathrm{a}$ \\
\hline Phosphorus salts, $10.0 \mathrm{ml}^{\mathrm{z}}$ & $12.5 \mathrm{a}$ & $12.5 \mathrm{a}$ & $25.0 \mathrm{a}$ & $0.0 \mathrm{a}$ & $62.5 \mathrm{bcd}$ & $75.0 \mathrm{~cd}$ \\
\hline Dimethomorph, $0.48 \mathrm{~g}$ & $25.0 \mathrm{bc}$ & $25.0 \mathrm{a}$ & $25.0 \mathrm{a}$ & $12.5 \mathrm{ab}$ & $25.0 \mathrm{ab}$ & $25.0 \mathrm{ab}$ \\
\hline Fosetyl-al, $6.0 \mathrm{~g}^{\mathrm{z}}$ & $25.0 \mathrm{bc}$ & $25.0 \mathrm{a}$ & $25.0 \mathrm{a}$ & $12.5 \mathrm{ab}$ & $37.5 \mathrm{abc}$ & $87.5 \mathrm{~d}$ \\
\hline Fenamidone, $0.31 \mathrm{ml}$ & $12.5 \mathrm{a}$ & $25.0 \mathrm{a}$ & $25.0 \mathrm{a}$ & $37.5 \mathrm{abc}$ & $50.0 \mathrm{bcd}$ & $50.0 \mathrm{bcd}$ \\
\hline Mancozeb, $1.8 \mathrm{~g}$ & $37.5 \mathrm{abc}$ & $37.5 \mathrm{ab}$ & $37.5 \mathrm{ab}$ & $12.5 \mathrm{ab}$ & $37.5 \mathrm{abc}$ & $37.5 \mathrm{abc}$ \\
\hline Mancozeb + zoxamide, $2.4 \mathrm{~g}$ & $37.5 \mathrm{abc}$ & $37.5 \mathrm{ab}$ & $37.5 \mathrm{ab}$ & $12.5 \mathrm{ab}$ & $25.0 \mathrm{ab}$ & $37.5 \mathrm{abc}$ \\
\hline Cyazofamid, $0.12 \mathrm{ml}$ & $62.5 \mathrm{bcd}$ & $75.0 \mathrm{bc}$ & $75.0 \mathrm{bc}$ & $62.5 \mathrm{c}$ & $75.0 \mathrm{~cd}$ & $87.5 \mathrm{~d}$ \\
\hline Mefenoxam, $0.9 \mathrm{ml}^{\mathrm{z}}$ & $75.0 \mathrm{~cd}$ & $75.0 \mathrm{bc}$ & $75.0 \mathrm{bc}$ & $50.0 \mathrm{bc}$ & $75.0 \mathrm{~cd}$ & $75.0 \mathrm{~d}$ \\
\hline Fluazinam, $0.62 \mathrm{ml}$ & $87.5 \mathrm{~d}$ & $87.5 \mathrm{c}$ & $87.5 \mathrm{c}$ & $62.5 \mathrm{c}$ & $62.5 \mathrm{bcd}$ & $75.0 \mathrm{~cd}$ \\
\hline Zoxamide, $0.37 \mathrm{~g}$ & $100.0 \mathrm{~d}$ & $100.0 \mathrm{c}$ & $100.0 \mathrm{c}$ & $50.0 \mathrm{bc}$ & $50.0 \mathrm{bcd}$ & $50.0 \mathrm{bcd}$ \\
\hline
\end{tabular}

y Percentage of plant death per treatment. Column means followed by the same letter are not significantly different (Fisher's least significant difference), $P=$ $0.05)$.

${ }^{\mathrm{z}}$ Registered for P. cactorum management on ginseng. 
use of apple fruit in assessing the virulence of isolates on ginseng did not appear to be a useful tool. The virulence of isolates observed in this research did not appear to be associated with the mefenoxam sensitivity or origin of the isolates.

Ginseng diseases caused by $P$. cactorum are highly destructive and fungicides are commonly required to limit plant loss. Mefenoxam, which is registered on ginseng, is primarily relied upon for $P$. cactorum control (13). Recently, P. cactorum resistance to mefenoxam was identified in isolates from strawberry roots and crowns (17). In this study, P. cactorum from ginseng was predominantly resistant to mefenoxam. When using inoculated apple fruit to test the efficacy of fungicides, the greatest level of disease was observed with the untreated inoculated and the mefenoxam-treated fruit. Similarly, the greatest level of disease and plant death was observed with the mefenoxam-treated ginseng seedlings. In our studies, mefenoxam did not perform well due to the use of a mefenoxam-resistant $P$. cactorum isolate. Although some disease control was observed with phosphorus salts and fosetyl-al, the number of infected fruit and infection on the apple fruit were variable among replications. The efficacy of fosetyl-al and phosphorus salts in managing $P$. cactorum on seedlings was not significantly better than the untreated control. The most effective fungicides for $P$. cactorum management on apple were dimethomorph, copper hydroxide, and fenamidone. For disease control on seedlings, copper hydroxide was consistently effective. Dimethomorph applications to seedlings typically provided good protection compared with other treatments. Using apple fruit to assess fungicide efficacy did not prove to be a good indicator of disease control on seedlings. Apple fruit were wounded prior to treatment and inoculation, which may have impacted our findings. However, in a natural setting, the pathogen may gain entry to internal plant tissues via insect feeding, mechanical injury, or natural plant openings. Perhaps the results on apple fruit would be better associated with managing foliar blight caused by $P$. cactorum than the root rot phase, which was tested in our study. Future studies could also utilize a pooled isolate mix to evaluate fungicide efficacy.

Although pathogens including Alternaria, Cylindrocarpon, Fusarium, and Trichoderma spp. (16) have been recovered from stratified ginseng seed, there are no documented cases of Phytophthora spp. In our study, it appears that $P$. cactorum can be disseminated via ginseng seed. Ginseng seed are not dried but kept moist throughout the handling and storage process until planting; therefore, $P$. cactorum may survive on the exterior of the seed, providing a significant disease threat to the American ginseng industry. $P$. cactorum is also seedborne on safflower (32). Currently, Maxim 4FS (fludioxonil; Syngenta Crop Protection) and Apron XL (mefenoxam; Syngenta Crop Protection) are registered for used on ginseng as seed treatments.

Historically, growers have utilized a floating technique in an effort to identify immature, nonviable, or severely diseased seed that should be discarded $(16,20,33)$. However, this process does not appear to be adequate in detecting Phytophthora spp. infection. With a limited number of fungicides registered for control of $P$. cactorum on ginseng, the identification and prevalence of mefenoxam resistance to $P$. cactorum is of great concern. Additional registered fungicides and new cultural strategies for sanitary seed handling and storage are needed to ensure high yields and root quality of this valuable specialty crop.

\section{ACKNOWLEDGMENTS}

This work was funded by the United States Department of Agriculture Cooperative State Research, Education, and Extension Service Pest Management Alternatives Program Award No. 2003-34381-13522 and the IR-4 Biopesticide Research Grant Program. We thank B. R. Harlan

Table 6. Evaluation of registered and unregistered fungicides for the control of a mefenoxam-resistant Phytophthora cactorum isolate on ginseng seedlings, 2006

\begin{tabular}{lcccc}
\hline & \multicolumn{4}{c}{ Seedling death $(\%)^{\mathbf{y}}$} \\
\cline { 2 - 5 } Treatments, rate/liter & 16 June & 19 June & 21 June & 28 June \\
\hline Untreated inoculated & $25.0 \mathrm{~b}$ & $25.0 \mathrm{ab}$ & $37.5 \mathrm{bc}$ & $87.5 \mathrm{~d}$ \\
Copper hydroxide, $3.6 \mathrm{~g}$ & $0.0 \mathrm{a}$ & $0.0 \mathrm{a}$ & $0.0 \mathrm{a}$ & $0.0 \mathrm{a}$ \\
Mancozeb, $1.8 \mathrm{~g}$ & $0.0 \mathrm{a}$ & $0.0 \mathrm{a}$ & $0.0 \mathrm{a}$ & $0.0 \mathrm{a}$ \\
Captan, $3.0 \mathrm{~g}$ & $0.0 \mathrm{a}$ & $0.0 \mathrm{a}$ & $0.0 \mathrm{a}$ & $0.0 \mathrm{a}$ \\
Fluazinam, $0.62 \mathrm{ml}$ & $0.0 \mathrm{a}$ & $0.0 \mathrm{a}$ & $0.0 \mathrm{a}$ & $0.0 \mathrm{a}$ \\
Dimethomorph, $0.48 \mathrm{~g}$ & $0.0 \mathrm{a}$ & $0.0 \mathrm{a}$ & $0.0 \mathrm{a}$ & $0.0 \mathrm{a}$ \\
Fosetyl-al, $6.0 \mathrm{~g} z$ & $0.0 \mathrm{a}$ & $12.5 \mathrm{ab}$ & $25.0 \mathrm{ab}$ & $25.0 \mathrm{ab}$ \\
Cyazofamid, $0.12 \mathrm{ml}$ & $0.0 \mathrm{a}$ & $0.0 \mathrm{a}$ & $0.0 \mathrm{a}$ & $0.0 \mathrm{a}$ \\
Fenamidone, $0.31 \mathrm{ml}$ & $0.0 \mathrm{a}$ & $0.0 \mathrm{a}$ & $0.0 \mathrm{a}$ & $0.0 \mathrm{a}$ \\
Mancozeb + zoxamide, $2.4 \mathrm{~g}$ & $0.0 \mathrm{a}$ & $0.0 \mathrm{a}$ & $0.0 \mathrm{a}$ & $0.0 \mathrm{a}$ \\
Mefenoxam, $0.9 \mathrm{ml}$ & $0.0 \mathrm{a}$ & $37.5 \mathrm{~b}$ & $62.5 \mathrm{c}$ & $75.0 \mathrm{~cd}$ \\
Phosphorus salts, $10.0 \mathrm{ml}^{\mathrm{z}}$ & $12.5 \mathrm{ab}$ & $25.0 \mathrm{ab}$ & $37.5 \mathrm{bc}$ & $50.0 \mathrm{bc}$ \\
Zoxamide, $0.37 \mathrm{~g}$ & $12.5 \mathrm{ab}$ & $37.5 \mathrm{~b}$ & $62.5 \mathrm{c}$ & $75.0 \mathrm{~cd}$ \\
\hline
\end{tabular}

y Percentage of plant death per treatment. Column means followed by the same letter are not significantly different (Fisher's least significant difference), $P=0.05$ ).

${ }^{\mathrm{z}}$ Registered for $P$. cactorum management on ginseng. and J. A. Woodworth for laboratory assistance and the Ginseng Growers of Michigan, Ginseng Board of Wisconsin, and Wisconsin Ginseng Growers Association for samples and collaboration.

\section{LITERATURE CITED}

1. Adam, K. L. 2004. Ginseng, goldenseal and other native roots. Horticulture technical note ATTRA Natl. Sustainable Agric. Inf. Serv. Publ. No. IP115.

2. Anonymous. 2000. American ginseng: vegetable crops production guide for the Atlantic Provinces. Atlantic committee on vegetables production guides. Atlantic provinces agricultural services coordinating committee. Online publication.

3. Blackwell, E. 1943. The life history of Phytophthora cactorum (Leb. \& Cohn.) Schröt. Trans. Br. Mycol. Soc. 26:71-89.

4. Blackwell, E. 1949. Terminology in Phytophthora with definitions and descriptions. Commonw. Mycol. Inst. Mycol. Pap. 30:1-21.

5. Bobev, S. G. 2003. First report of Phytophthora cactorum on American ginseng (Panax quinquefolius) in Bulgaria. Plant Dis. 87:752.

6. Curran, D. F. 1985. The Ginseng Disease and Pest Reference Guide. D. F. Curran Productions, Hamburg, WI.

7. Darmono T. W., Owen, M. L., and Parke, J. L. 1991. Isolation and pathogenicity of Phytophthora cactorum from forest and ginseng gardens in Wisconsin. Plant Dis. 75:610-612.

8. Davis, J., and Shoemaker, P. B. 1999. Ginseng disease control-Phytophthora and $\mathrm{Al}$ ternaria. Hortic. Inf. Leaflet no. 132. North Carolina State University and A\&T State University.

9. Dekker, J. 1987. How to conduct and measure fungicide resistance. Pages 153-163 in: Experimental Techniques in Plant Disease Epidemiology. J. Kranz and J. Rotem, eds. Springer, New York.

10. Erwin, D. C., and Ribeiro, O. K. 1996. Phy tophthora Diseases Worldwide. American Phytopathological Society Press, St. Paul, MN

11. Gevens, A. J., Donahoo, R. S., Lamour, K. H., and Hausbeck, M. K. 2007. Characterization of Phytophthora capsici from Michigan surface irrigation water. Phytopathology 97:421-428.

12. Harrison, H. C., Parke, J. L., Oelke, E. A., Kaminski, A. R., Hudelson, B. D., Martin, L. J., Kelling, K. A., and Binning, L. K. 2000. Ginseng. Alternative field crops manual. University of Wisconsin Extension, Cooperative Extension University of Minnesota Center for Alternative Plant and Animal Products, and the Minnesota Extension Service. Online publication.

13. Hausbeck, M. K. 2004. Pest management in the future. A strategic plan for the Michigan and Wisconsin ginseng industry. USDA Regional IPM Centers, Center Products, PMSPs, Ginseng, archived, 04/13/2004. Online publication.

14. Hill, S. N., and Hausbeck, M. K 2005. Characterization of Phytophthora cactorum isolated from American ginseng. (Abstr.) Phytopathology 95:S163.

15. Hill, S.N., Hausbeck, M.K., Woodworth, J.A., and Harlan, B.R. 2005. Detection of Phy tophthora cactorum on ginseng seed and screening pathogen isolates for resistance to mefenoxam (Abstr.). Phytopathology 95:S42.

16. Hobson, J. M. 1999. Spring seeding, seed size and seed pathology of North American ginseng (Panax quinquefolius L.). M.S. thesis, University of Guelph.

17. Jeffers, S. N., and Schnabel, G. 2004. First report of resistance to mefenoxam in Phytophthora cactorum in the United States and elsewhere. Plant Dis. 88:576.

18. Lamour, K. H., and Hausbeck, M. K. 2000. Mefenoxam insensitivity and the sexual stage 
of Phytophthora capsici in Michigan cucurbit fields. Phytopathology 90:396-400.

19. Lamour, K. H., and Hausbeck, M. K. 2003. Susceptibility of mefenoxam-treated cucurbits to isolates of Phytophthora capsici sensitive and resistant to mefenoxam. Plant Dis. 87:920922.

20. Polczinski, L. C. 1982. Ginseng (Panax quinquefolius L.) culture in Marathon County, Wisconsin: historical growth, distribution and soils inventory. M.S. thesis, University of Wiscon$\sin$

21. Pritts, K. D. 1995. Ginseng: How to Find, Grow and Use America's Forest Gold. Stackpole Books, Mechanicsburg, PA.

22. Proctor, J. T. A. 1996. Ginseng: Old Crop, New Directions. J. Janick, ed. ASHS Press, Alexandria, VA

23. Proctor, J. T. A., and Bailey, W. G. 1987. Gin- seng: industry, botany, and culture. Hortic. Rev. 9:187-236.

24. Proctor, J. T., A. and Louttit, D. 1995. Stratification of American ginseng seed: embryo growth and temperature. Korean J. Ginseng Sci. 19:171-174.

25. Punja, Z. K. 1997. Fungal pathogens of American ginseng (Panax quinquefolium) in British Columbia. Can. J. Plant Pathol. 19:301306.

26. Putnam, M. L. 1984. Studies of Phytophthora cactorum (Leb. \& Cohn) Schröet and Rhizoctonia solani Kühn on American ginseng (Panax quinquefolium L). M.S. thesis, University of Wisconsin, Madison.

27. Putnam, M. L., and Mitchell, J. E. 1984. The use of metalaxyl to control Phytophthora root rot of ginseng (Panax quinquefolium) (Abstr.) Phytopathology 74:854.
28. Rahimian, M. K., and Mitchell, J. E. 1988. Detection and quantification of Phytophthora cactorum in naturally infested soils. Phytopathology 78:949-952.

29. Schmitthenner, A. F., and Bhat, R. G. 1994 Useful methods for studying Phytophthora in the laboratory. OARDC Spec. Circ. 143:1-16.

30. Tucker, C. M. 1931. Taxonomy of the genus Phytophthora de Bary. Univ. Minn. Agric. Exp. Res. Stn. Bull. 153. Online publication.

31. Van Hook, J. M. 1906. A disease of ginseng due to Phytophthora sp. Crops 5:94.

32. Zad, S.J. 1992. Safflower seed-borne diseases Meded. Fac. Landbouwwet. Rijksuniv. Gent 57(2a):161-163.

33. Ziezold, A. M., Reeleder, R. D., Hall, R., and Proctor, J. T. 1998. Seedborne, fungi and fungicide seed treatment of ginseng. J. Ginseng Res. 22(4):229-236. 